\title{
Legal Protection Against Bank Customers in Review of Banking Laws
}

\author{
Sri Dewi ${ }^{1}$, Miftah Hulzannah ${ }^{1}$, Maria Panggabean ${ }^{1}$, Riki Afri Rizki ${ }^{1}$, Sriono $^{1 *}$ \\ Student of the Law Study Program, Faculty of Law, Labuhanbatu University \\ ${ }^{*}$ Lecturer at the Law Study Program, Faculty of Law, Labuhanbatu University \\ Corespondent Author \\ *Email: sriono.mkn@gmail.com
}

\begin{abstract}
.
Legal protection for customers is reviewed in terms of banking laws and regulations, such as Law Number 21 of 2008 concerning Islamic banking. Both Islamic banks and conventional banks with regulatory control must comply with general banking regulations. Act Number 7 of 1992 concerning Banking. The Banking Law which regulates amendments to Law Number 10 of 1998 concerning Amendments to Law Number 7 of 1999. there is an obligation for banks to become members of the Deposit Insurance Corporation (LPS) so as to provide protection for depositors customers against their deposits and the existence of customer rights conduct customer complaints, and use banking mediation forums for simple, cheap, and fast dispute resolution.Legal protection for customers in terms of the Consumer Protection Act lies in the obligation for banks to heed the procedure for making standard clauses. Settings via The Consumer Protection Law which is closely related to legal protection for customers as banking consumers is the provision regarding standard clauses. Meanwhile, from the laws and regulations in the banking sector, the provisions that provide legal protection for bank customers as consumers include the introduction of the Deposit Insurance Corporation (LPS) in Law Number 10 of 1998. At the technical level the legal umbrella protecting customers includes the existence of arrangements regarding the settlement of customer complaints and banking mediation in a Bank Indonesia Regulation (PBI).
\end{abstract}

Keywords :Legal protection,Customer, Bank, Law

\section{INTRODUCTION}

Every person or business entity that is trying to increase consumptive and productive needs is in dire need of funding, either in the form of credit, considering that the capital owned by a company or individual is usually not sufficient to support its business expansion. A bank is a financial institution that is a place for people to keep their funds based solely on the belief that their money will be recovered on time and accompanied by a reward in the form of interest [1]. This means that the existence of a bank is very dependent on the public's trust. The higher the public's trust, the higher the public awareness to save their money in the bank and use other banking services. Public trust is the main keyword for the development or failure of a bank,

Banking institutions are institutions that rely on public trust for the continuity of their business. Thus, in order to perpetuate public trust in banks, the government must try to protect the public as bank customers. If there is a decline in the level of public trust in banking institutions, it will be a disaster for the country's economy as a whole and this situation is difficult to recover. As happened when 16 banks were liquidated in 1997, as a result, a number of banks experienced a rush, as a result of the collapse of public confidence in national banking. The existence of banking institutions currently has a fairly dominant contribution in advancing the banking business, of course, does not escape the role of customers as consumers of products [2]. 
Consumers of banking services are better known as customers. In banking practice, customers are divided into three, namely: First, depositor customers, namely customers who deposit their funds in a bank, for example in the form of demand deposits, savings and time deposits. Second, customers who take advantage of bank credit or financing facilities, for example housing loans, murabahah financing, and so on. Third, customers who make transactions with other parties through banks (walk in customers), for example transactions between an importer as a buyer and an exporter abroad using the letter of credit (L / C) facility [3].

The Banking Law in article 1 paragraph 1 states that a bank is a business entity that collects funds from the public in the form of deposits and distributes them to the public in order to improve the standard of living of many people. Based on the two main functions of the bank, namely the function of raising funds and the function of channeling funds, there are two legal relationships between the bank and its customers, namely:

\section{Legal Relationship Between the Bank and Fund Depositors}

This means that the bank places itself as a borrower of funds belonging to the community who acts as an investor. The form of a legal relationship between a bank and a depositing customer can be seen from the legal relationship that arises from banking products, such as deposits, savings, current accounts and the like. The form of this legal relationship can be contained in the form of bank regulations and general conditions that must be obeyed by every customer depositing funds. These requirements must be adjusted to existing banking products, because the terms of a banking product will not be the same as those of other banking products. In banking products such as savings and time deposits,

\section{Legal Relationships Between Banks and Debtor Customers}

This means that the bank as an institution that provides funds for its debtors. It can take the form of credit, such as working capital loans, investment loans or small business loans. The legal relationship between the customer and the bank related to the agreement between the two parties is a civil issue that has the potential to cause a dispute if one of the parties breaks the promise or defaults. Civil disputes between customer banks arise from financial transactions conducted by both parties. In general, civil disputes are disputes that occur in the jurisdiction of material and individual laws caused by one of the parties violating the principle of public interest. These disputes usually arise as a result of not fulfilling the principles of engagement law.

\section{RESEARCH METHODS}

The research method used in this study is to use the normative juridical method, which refers to the provisions of positive laws and regulations in Indonesia, among the laws and regulations on legal protection for bank customers which are reviewed from banking laws by knowing the procedures of rule of law and make it a guide in solving problems that exist in society.

In this research, it refers to secondary data research. Thus there are main activities that will be carried out in carrying out this research, namely library research, which is obtained through literature, by reviewing, analyzing, and managing the literature on legislation by researching through articles related to problems to be examined.

\section{DISCUSSION}

\section{Legal Protection for Customers Judging from Law Number 8 of 1999 concerning Consumer Protection}

The Consumer Protection Law (UUPK) is not the only one that regulates consumer protection in Indonesia. Previously, there were laws and regulations that protect the interests of consumers, including: Articles 202-205 of the Criminal Code, Ordinance of Hazardous Materials (1949), Law Number 1 of 1995 concerning Limited Liability Companies, Law Number 10 of 1998 concerning 
Amendments On Act Number 7 of 1992 concerning Banking, and so on. The existence of such conditions, the background of the UUPK provides regulations regarding standard clauses, namely as follows [5]:

a. In offering goods and / or services intended for trading, business actors are prohibited from making or including standard clauses on each document and / or agreement if:

i. states the transfer of responsibility of business actors;

ii. states that the business actor has the right to refuse the return of goods purchased by consumers;

iii. states that the business actor has the right to refuse the return of money paid for goods and / or services purchased by consumers;

iv. states that the power of attorney from consumers to business actors, either directly or indirectly, to carry out all unilateral actions relating to goods purchased by consumers in installments

v. regulate evidence regarding the loss of use of goods or use of services purchased by consumers;

vi. give business actors the right to reduce the benefits of services or reduce the assets of consumers which are the object of sale and purchase of services;

vii. declare the consumer's submission to regulations in the form of new, additional, advanced and / or further amendments made unilaterally by business actors during the period when the consumer utilizes the service purchased;

viii. states that the consumer authorizes the business actor to impose a mortgage, lien, or security right on goods purchased by consumers in installments.

b. Business actors are prohibited from including standard clauses whose location or shape is difficult to see or cannot be read clearly, or whose disclosures are difficult to understand.

c. Every standard clause that has been stipulated by the business actor in a document or agreement that meets the provisions as intended in paragraphs 1 and 2 shall be declared null and void by law.

d. Business actors are obliged to adjust standard clauses that are contradictory to the Law

\section{Legal Protection for Customers Viewed from the Laws and Regulations in the Banking Sector}

As mentioned above, the legal regulations that provide protection for customers are not only the UUPK, but are more specific to the laws and regulations in the banking sector. Banks are financial institutions that carry out business activities by withdrawing funds directly from the public, so it is necessary to implement the fiduciary principle [6].

First, to provide legal protection for depositor customers, Law Number 10 of 1998 mandates the establishment of the Deposit Insurance Corporation (LPS) and requires each bank to guarantee public funds deposited in the bank concerned. This mandate has been realized with the enactment of Law Number 24 of 2004 concerning the Deposit Insurance Corporation. Its function is to guarantee deposits from depositing customers and to take an active part in maintaining the stability of the banking system in accordance with its authority [7].

Second, legal protection for customers, especially in the event of a dispute between a customer and a bank. This is regulated through PBI No. 7/7 / PBI / 2005 concerning Resolution of Customer Complaints [8] as amended by PBI No. 10/10 / PBI / 2008 and PBI No. 8/5 / PBI / 2006 concerning Banking Mediation as amended by PBI No. 10/1 / PBI / 2008 [9]. As for the organizers of Banking Mediation according to Article 3 of PBI No. 8/5 / PBI / 2006, namely an independent banking Mediation Institute formed by a banking association [10]. The proceedings in Banking Mediation are technically regulated in PBI No. 8/5 / PBI / 2006 and Bank Indonesia Circular Letter No. 8/14 / DPNP dated June 1, 2006, as follows: 
a) Submission of Dispute settlement in the context of banking Mediation to Bank Indonesia is conducted by the Customer or Customer Representative.

b) If a Customer or a Customer Representative submits a Dispute resolution to Bank Indonesia, the Bank is obliged to comply with the summons of Bank Indonesia.

In Indonesia it also has a mission, and a special function related to banking institutions that can be directed as agents of development, namely as an institution that aims to support the implementation of national development in order to increase equitable distribution of development and its results, economic growth and national stability towards improving the standard of living of the people at large.

The requirements for submitting dispute resolution through banking mediation are as follows:

a) Submitted in writing, accompanied by adequate supporting documents;

b) The customer has once submitted an attempt for resolution to the Bank;

c) The submitted dispute is not in process or has never been decided by an arbitration institution or court, or there is no agreement facilitated by another Mediation institution;

d) The dispute submitted is a civil dispute;

e) The proposed dispute has never been processed in banking Mediation facilitated by Bank Indonesia; and

f) Submission of Dispute resolution does not exceed 60 (sixty) working days from the date of the result of the Complaint settlement submitted by the Bank to the Customer

With regard to legal protection for depositors of funds, the authors divide it into 2 types, namely indirect protection and direct protection.

\section{a) Indirect Protection}

Indirect protection by the banking world against the interests of depositors of funds is a legal protection provided to depositors of funds against the risk of loss arising from a policy or arising from business activities conducted by banks [11]. This is an effort and internal preventive action by the bank concerned by means of the following:

1. The Precautionary Principle

This principle requires banks to always be careful in carrying out their business activities, meaning that they must always be consistent in implementing laws and regulations in the banking sector based on professionalism and good faith. Among other things, implementing the provisions on the maximum credit limit, granting guarantees, placement of investment in securities, or other similar rights, which can be done by banks to borrowers or a group of related borrowers, including companies in the same group as the bank concerned. determined by Bank Indonesia [12].

2. Maximum Credit Lending Limit

This aims to maintain bank health and increase bank resilience by spreading risk in the form of credit placements to various borrowing customers. In addition, this provision is to prevent the provision of credit to borrowers or certain groups of borrowers. In this regard, according to a Bank Indonesia Decree, the Legal Lending Limit is the percentage ratio of the maximum allowable provision of funds to bank capital. BI stipulates that for borrowers or groups of borrowers who are not related parties is $20 \%$ of the capital, while for borrowers or groups of borrowers who are related is $10 \%$ of capital [13].

3. Obligation to Announce Balance Sheet and Profit and Loss Calculation

The existence of this provision is contained in Articles 34 and 35 of Law No. 10 of 1998, in order to provide information to the public, especially depositors, regarding the soundness of the bank and other matters related to the bank.

4. Bank Mergers, Consolidations and Acquisitions 
Business actors have many reasons and objectives for this. One of the most important things is to increase efficiency and enhance company competitiveness. However, in doing this it is not done freely but is limited by the relevant laws and regulations, namely Law No. 28 of 1999 concerning Bank Mergers, Consolidations and Acquisitions. In conducting Mergers, Consolidations and Acquisitions, a Bank must consider the interests of all parties, namely the interests of the bank, the interests of creditors, the interests of minority shareholders and bank employees, as well as the interests of the people at large and fair competition in conducting bank business.

\section{b) Immediate Protection}

Direct protection by the banking world against the interests of depositors of funds is a protection provided to depositors of funds directly against the possibility of risk of loss from business activities carried out by the bank. According to article 19 paragraphs (1) and (3) of the Consumer Protection Act, consumers who feel that they are at a disadvantage can demand direct compensation from producers and producers must provide responses/settlement within 7 days after the transaction takes place [14].

\section{CONCLUSION}

Safeguards for debtor customers against the risks they experience in bank credit agreements can not only be implemented by implementing Article 18 of the Consumer Protection Act, but also in accordance with Bank Indonesia policies. In early 2002, Bank Indonesia began compiling a blueprint for the national banking system, one of which includes efforts to protect and empower customers. LPS in the banking system is considered central to be an institution that convinces customers regarding their savings even though their financial conditions deteriorate. Legal safeguards for consumers that are not guaranteed by the LPS will be beheaded based on bank law with customers based on a contractual relationship, namely what is meant is always transformed into consumer sovereignty as well as a burden on the bank to complete it as promised if the bank does not fulfill it will be deemed to have defaulted, then The customer can sue based on the aforementioned provisions, based on a non-contractual relationship where the deposit value of up to two billion will get its right from the disbursement of bank assets during the liquidation process in the sixth order, legal protection can file an objection to the IDIC or take legal action through the court for the act against the law. Thus, the government is expected to continue to disseminate information to the public regarding the regulations related to LPS, and the public is advised to better understand the LPS.

In general, in terms of Law Number 10 of 1998, legal protection for bank customers is very weak, because most of the articles in the bank are only concentrated on the aspects of bank interests. Legal protection for sharia bank customers as consumers is viewed from the legislation in the banking sector, for example, there is an obligation for banks to become members of the IDIC so as to provide protection for customers. In addition, there is also the right for customers to file customer complaints and use banking mediation forums to obtain dispute resolution.

\section{REFERENCE}

[1] Undang-Undang Nomor 10 Tahun 1998 tentang Perubahan Atas Undang-Undang Nomor 7 Tahun 1992 tentang Perbankan

[2] Muhammad Djumhana, Hukum perbankan di indonesia, Citra Aditya Bakti, Bandung,2000

[3] Gunawan Widjaja dan Ahmad Yani, Hukum Tentang Perlindungan Konsumen, PT. Gramedia Pustaka Utama, Jakarta, 2003

[4] Peraturan Bank Indonesia Nomor 7/7/PBI/2005 tentang Penyelesaian Pengaduan Nasabah

[5] Undang-Undang Nomor 8 Tahun 1999 tentang Perlindungan Konsumen 
[6] Az. Nasution, 2003, “Aspek Hukum Perlindungan Konsumen: Tinjauan Singkat UU No. 8 Tahun 1999L.N. 1999 No. 42”, Artikel pada Teropong, Media Hukum dan Keadilan (Vol II, No. 8, Mei 2003), MaPPIFH UI dan Kemitraan.

[7] Undang-Undang Nomor 24 Tahun 2004 tentang Lembaga Penjamin Simpanan

[8] Surat Edaran Bank Indonesia No. 7/24/DPNP tertanggal 18 Juli 2005 tentang Penyelesaian Pengaduan Nasabah.

[9] Surat Edaran Bank Indonesia No. 8/14/DPNP tanggal 1 Juni 2006 tentang Mediasi Perbankan.

[10] Peraturan Bank Indonesia Nomor 8/5/PBI/2006 tentang Mediasi Perbankan

[11] Ahmad Miru, Prinsip-prisnip Perlindungan Hukum bagi Konsumen Indonesia, Raja Grafindo Persada, Jakarta, 2011)

[12] Gunawan Widjaja dan Ahmad Yani, Hukum Tentang Perlindungan Konsumen, PT. Gramedia Pustaka Utama, Jakarta, 2003

[13] Johannes Ibrahim, Cross Default dan Cross Collateral Sebagai Upaya Penyelesaian Kredit Bermasalah, PT. Revika Aditama, Bandung, 2004

[14] Janus sidabalok,. Hukum Perlindungan Konsumen di Indonesia, Penerbit PT.Citra Aditya Bakti, Bandung, 2006 